\title{
Kirjallisuus historiantulkintana, mahdollisen taju ja Jonathan Littellin Hyväntahtoiset
}

Parin viime vuosikymmenen aikana romaanikirjallisuutta ympäri maailmaa on leimannut ennennäkemätön historiabuumi. Etenkin toisen maailmansodan perintö on ollut vilkkaan uudelleentulkinnan kohteena. Samaan aikaan kulttuurisen muistin tutkimus on muotoutunut suosituksi tutkimusalueeksi, joka tarkastelee kirjallisuuden roolia menneisyyden tulkitsijana ja merkityksellistäjänä. Kirjallisuudentutkimuksessa ei kuitenkaan vallitse minkäänlaista yksimielisyyttä siitä, voiko fiktio tuottaa historiallista ymmärrystä ja jos voi, niin missä mielessä. Monet fiktion erityisluonnetta teoretisoineet tutkijat - mahdollisten maailmojen teoriasta "epäluonnolliseen narratologiaan" - korostavat historian ja fiktion jyrkkää eroa ja esittävät, että kirjallisuus on pikemmin esteettisen mielihyvän kuin historian ymmärtämisen lähde. Tässä keskustelussa on keskeisessä roolissa aktuaalisen ja mahdollisen välinen vastakkainasettelu, jota on käytetty aina Aristoteleesta lähtien historian ja kirjallisuuden välisen suhteen käsitteellistämiseen. Esitän artikkelissani, että tämä vastakkainasettelu on usein kytköksissä ongelmallisiin historian ja todellisuuden luonnetta koskeviin ontologisiin oletuksiin, joiden pohjalta on vaikea hahmottaa, miten kirjallisuus tuottaa historiaa koskevaa ymmärrystä. Kun fiktion ajatellaan käsittelevän mahdollista ja historian aktuaalista, jää helposti huomaamatta, miten mahdollisen taju konstituoi jokaista aktuaalista maailmaa, miten kirjallisuus tarjoaa tulkintoja aktuaalisista maailmoista ja miten sillä on omat kirjalliset keinonsa käsitellä mennyttä maailmaa mahdollisuustilana.

Havainnollistan argumenttiani analysoimalla Jonathan Littellin romaania Hyväntahtoiset (2008, alkuper. Les Bienveillantes, 2006), joka on viime vuosien kohutuimpia holokaustiromaaneja. Tätä kokonaan ensimmäisessä persoonassa kerrottua, entisen SS-upseeri Maximilien Auen muistelmien muotoon kirjoitettua romaania on kritisoitu niin historiallisesta epäuskottavuudesta kuin eettisesti kyseenalaisesta yrityksestä houkutella lukija samaistumaan natsiupseeriin. Samalla se on toistuvasti mainittu 2000-luvun merkittävimmäksi romaaniksi. Romaanin puolustajat ovat korostaneen sen merkitystä historiantulkintana ja kulttuurisen muistin muovaajana (esim. Semprún 2008, 35; Beevor 2009).

Hahmottelen artikkelissani aktuaalisen/referentiaalisen ja mahdollisen/eireferentiaalisen välisestä vastakkainasettelusta lähtevän teoretisoinnin vaihtoehdoksi narratiivista hermeneutiikkaa lähestymistapana, joka näkee historiankirjoituksen 
ja kaunokirjallisuuden erilaisina tapoina tulkita (mennyttä tai nykyistä) maailmaa ja on sensitiivistä kaunokirjallisuuden erityisyydelle, sen tavoille edellyttää erityisiä tulkintatapoja. ${ }^{1}$ Analysoin, miten kaunokirjallisuus voi toimia samanaikaisesti sekä immersiivisesti, kutsuen lukijaa eläytymään ja uppoutumaan kerrottuun maailmaan, että itserefleksiivisesti, kriittistä etäisyyttä tuottaen, ja esitän, että tästä jännitteestä syntyvä lukemisen dynamiikka on keskeistä Hyväntahtoiset-romaanin tavalle kontribuoida historiaa koskevaan ymmärrykseemme ja laajemminkin kaunokirjallisuuden toimintatavalle. Tämän dynamiikan pohjalta kirjallisuus voi samanaikaisesti tulkita mennyttä maailmaa mahdollisuustilana - tavalla, joka kultivoi lukijoiden mahdollisen tajua - ja pohtia historian esittämisen mahdollisuuksia ja rajoja.

\section{Aktuaalinen ja mahdollinen}

Monet fiktion teoreetikot erottelevat fiktion ja ei-fiktion mahdollisen ja aktuaalisen käsitteillä ja korostamalla fiktion ei-referentiaalisuutta. Esimerkiksi Dorrit Cohn (2006, 26) ja Lubomír Doležel $(2010,41)$ esittävät tästä lähtökohdasta Gottlob Fregeä (2008/1892) seuraten, että fiktiivisiltä teksteiltä puuttuu ylipäätään totuusarvo. Doleželin mukaan historiantutkimus konstruoi mahdollisia maailmoja, jotka toimivat aktuaalisten maailmojen malleina, kun taas historialliset romaanit rakentavat mahdollisia maailmoja, joissa keksityt henkilöhahmot toimivat rinnakkain fiktionalisoitujen historiallisten hahmojen kanssa ja jotka eivät siten voi toimia minkään aktuaalisen menneen maailman mallina: "Mahdollinen maailma, jossa historiallisten henkilöiden vastineet elävät yhdessä, ovat vuorovaikutuksessa ja kommunikoivat fiktiivisten henkilöhahmojen kanssa, ei ole historiallinen maailma." (Doležel 2010, 36; suom. HM.) Samaan tapaan Cohn (2006, 22-26) määrittelee fiktion "ei-referentiaaliseksi kertomukseksi" ja toteaa fiktiivisten maailmojen, kuten Kafkan Linnan maailman, olevan "kokonaan erillään todellisesta [actual] maailmasta"; hänestä "totuuden ja epätotuuden näkökulmasta" voidaan arvioida vain "todellisia tapahtumia ja henkilöitä käsitteleviä" ei-fiktiivisiä kertomuksia.

Hahmotellessaan, miten fiktionaalisuus toimii retorisena strategiana, myös Henrik Skov Nielsen, James Phelan ja Richard Walsh $(2015,68,71)$ asettavat vastakkain aktuaalisen ja mahdollisen ja liittävät fiktionaalisen epätodellisen (unreal) alueeseen, mutta he huomioivat, että vaikka fiktiivinen teksti ei ole tarkoitettu otettavaksi vastaan "totena", se voi silti vaikuttaa käsityksiimme siitä, mikä on "aktuaalista, faktuaalista ja todellista". On kuitenkin epäselvää, miten tämä yhteys tulisi ymmärtää heidän käsitteellisistä lähtökohdistaan. Mitä ylipäätään tarkoitetaan "aktuaalisella", "faktuaalisella" ja "todellisella"?

Aktuaalisen ja mahdollisen suhteen hahmottaminen riippuu olennaisesti siitä, minkälaiseen todellisuus- ja historiakäsitykseen tutkijat nojaavat. Todellisuuden ja histo- 
rian luonnetta koskevia ontologisia oletuksia ei eksplikoida kyseisissä teoretisoinneissa: taustalla on itsestään selvinä pidettyjä oletuksia, jotka eivät kuitenkaan ole itsestään selviä. Fiktionaalisuuden teoria perustuu aina tiettyyn faktuaalisuuden teoriaan. Aktuaalisen ja mahdollisen vastakkainasettelulle rakentuva fiktionaalisuuden teoria näyttää useimmiten nojaavan näkemykseen siitä, että aktuaalista ja todellista on se, mikä voidaan objektiivisesti havaita: havainnoilla tai dokumenteilla todennettavissa olevat teot, tapahtumat ja tosiasiat. Mutta entä jos todellisuus, sen enempää mennyt kuin nykyinen, ei koostu vain teoista, tapahtumista ja tosiasioista? Eikö todellisuus rakennu myös näkymättömistä asioista, kuten kokemisen ja tuntemisen tavoista, tavoista merkityksellistää maailmaa ja suuntautua menneeseen, nykyiseen ja tulevaan?

Esimerkiksi Martin Heideggerin (1927), Hans-Georg Gadamerin (1960), Michel Foucault'n (1966) ja Reinhart Koselleckin (1979) ajattelun pohjalta historiallinen maailma voidaan käsitteellistää eräänlaiseksi mahdollisuustilaksi, jossa on mahdollista kokea, ajatella, tehdä, tietää ja kuvitella tiettyjä asioita, toisia taas vaikeaa tai mahdotonta. Koselleckin käsittein mahdollisen kokemusta tietyssä historiallisessa maailmassa määrittää suhde tuolle maailmalle ominaisen kokemustilan (Erfahrungsraum) ja odotushorisontin (Erwartungshorizont) välillä: menneisyyden läsnäolo nykyhetkessä ja tapamme suuntautua tulevaan ohjaavat sitä, miten asiat koetaan nykyhetkessä, ja nämä kokemisen tavat konstituoivat tuota maailmaa intersubjektiivisena merkitystodellisuutena. Nykyinen kulttuurihistoria on haastanut tämäntyyppisestä näkökulmasta "historiallisen realismin", jonka mukaan historia koostuu havaittavista teoista, ja sen sijaan korostaa, että mennyttä maailmaa konstituoivat myös ajatukset, tunteet, representaatiot, se mikä on näkymätöntä ja katoavaa; se esittää, että menneen maailman tutkimukselle on keskeistä menneiden mahdollisuuksien kartoittaminen (Salmi 2011, 173-174). Tässä tehtävässä historioitsija tarvitsee paitsi lähteitä ja sen selvittämistä, mitä menneisyydestä voidaan varmuudella tietää, myös kuvittelukykyä. ${ }^{2}$

Yllä hahmoteltu todellisuuskäsitys sopii yhteen sen hermeneuttisen ajattelutavan kanssa, että jo kokemuksella itsessään on tulkinnallinen rakenne: olemme aina jo suuntautuneet maailmaan tietyllä tavalla, jäsentäneet ja tulkinneet sitä tietystä kulttuurishistoriallisesta merkityshorisontista. Tästä näkökulmasta kokemuksia tulkitsevat kertomukset voidaan nähdä tulkintojen tulkintoina, ja kun uudelleentulkitsemme kokemuksiamme (kaunokirjallisten ja historiallisten) kulttuuristen kertomusten välityksellä, voidaan puhua kolmoishermeneutiikasta (Meretoja 2014a). Narratiivisen hermeneutiikan näkökulmasta sekä historiantutkimukselliset että historiaa käsittelevät kaunokirjalliset esitykset toimivat menneen maailman tulkintoina ja pyrkivät hahmottamaan sitä mahdollisuustilana. ${ }^{3}$ Kaunokirjallisuus on vapaampaa kuvittelemaan, mitä menneessä maailmassa olisi voinut tapahtua; historiantutkimusta sitoo dokumentoinnin vaatimus. Mutta molemmille on tärkeää sen kuvitteleminen, mikä tuossa maailmassa oli mahdollista ja mikä siinä koettiin mahdolliseksi. 
Paul Ricœur $(1985,347)$ toteaa tämänkaltaisesta hermeneuttisesta näkökulmasta, että fiktio voi tunnistaa menneisyydessä piileviä mahdollisuuksia. Vaikka Cohn (2006, 19) viittaa juuri Ricœuriin määritellessään fiktion "ei-referentiaaliseksi kertomukseksi”, Ricœur etenee Temps et récit-teossarjassaan (1983-1985) tästä yksinkertaistavasta alkulähtökohdasta sen pohdintaan, miten referentiaalisuuteen perustuva ajattelu on riittämätöntä fiktion ja todellisuuden suhteen ymmärtämisessä. Ricœurin mukaan on yhtä lailla syytä kritisoida "naiivia 'todellisuuden' käsitettä" kuin "naiivia 'epätodellisen' käsitettä, jota sovelletaan kaunokirjallisiin esityksiin". Hänen ajattelussaan mimesis näyttäytyy prosessina, joka on samanaikaisesti sekä performatiivista että tulkinnallista: "Tässä saavutamme pisteen, jossa löytämistä ja keksimistä ei voi erottaa toisistaan toisin sanoen pisteen, jossa referenssin käsite ei enää toimi.” (Ricœur 1985, 285; suom. HM.) Sen huomioiminen, miten aktuaalinen ja mahdollinen jatkuvasti läpäisevät toisensa, mahdollistaa sen analysoimisen, miten kaunokirjallisuus kuvittelun taiteena voi syventää ymmärrystämme menneistä maailmoista mahdollisuustiloina.

\section{Natsi-Saksa mahdollisuustilana}

Kysymys mahdollisesta läpäisee Hyväntahtoiset-romaania monella tasolla. Romaani ei kerro vain siitä, mitä tapahtui, vaan pyrkii kuvittelemaan, miten oli mahdollista että tapahtui mitä tapahtui. Se kuvittelee kertomuksen muodossa, mitä toimijat kokivat mahdolliseksi tuossa historiallisessa maailmassa ja mikä heille olisi saattanut olla mahdollista jälkikäteen ajateltuna, ajallisen välimatkan muokkaamasta näkökulmasta. Samalla se reflektoi, mitä meidän on mahdollista tietää tuosta maailmasta ja mitä ajattelun ja olemisen mahdollisuuksia kaunokirjallinen historiantulkinta voi avata meille nykymaailmassa.

Romaani osoittaa monisyisesti, miten aktuaalinen ja mahdollinen ovat kietoutuneet toisiinsa sekä menneisyydessä että nykyisyydessä. Kuvaamiensa tapahtumien maailmassa Aue on paikalla ja näkee mitä tapahtuu, mutta mitään varmuutta ei ole siitä, mitä pinnan alla tapahtuu, mitä ihmisten pään sisällä liikkuu ja millaiset näkymättömät voimat ohjaavat heidän toimiaan. Aue katsoo ukrainalaissotilaita, jotka natsit pakottavat teloittamaan juutalaisia, ja yrittää kuvitella, keitä he ovat, mistä he ovat tulleet ja mitä he myöhemmin ajattelisivat teoistaan:

Mietin noita ukrainalaisia: miten he olivat päätyneet sinne? Useimmat olivat taistelleet ensin puolalaisia, sitten venäläisiä vastaan, he olivat varmasti haaveilleet paremmasta tulevaisuudesta, itselleen ja lapsilleen, ja nyt he löysivät itsensä metsästä vieraassa asepuvussa tappamassa ihmisiä, jotka eivät olleet tehneet heille mitään, ymmärtämättä syytä. Mitä he mahtoivat ajatella? [--] Mitä he ajattelisivat myöhemmin siitä kaikesta? (Hyväntahtoiset, 78; tästä eteenpäin $\mathrm{H}.)^{4}$

Kertojan tapa pohtia näitä asioita silminnäkijän roolissa korostaa, että kysymys siitä, mikä on tämä maailma, jossa holokausti toteutettiin, oli akuutti jo tuolloin, tapahtuma- 
hetkellä. Se ei ollut jotain, minkä saattoi yksinkertaisesti nähdä. Se vaati mahdollisen kuvittelemista. Ylipäätään tietoisuus erilaisista mahdollisuuksista ja vaihtoehtoisista elämänkuluista sekä tarve etsiä yhteyksiä menneen, nykyisen ja tulevan välillä ohjaa sitä, miten asiat koetaan jo alun perin: "Ajattelin elämääni, sitä, millainen se olisi voinut olla ja miten sen olin elänyt [--] ja sitä, mitä juuri sillä hetkellä tapahtui.” $(\mathrm{H}, 86 .)^{5}$

Päähenkilö ja muut henkilöhahmot orientoituvat nykyhetkeen ja tulevaan sen pohjalta, minkälainen heidän odotushorisontistaan on muotoutunut aiempien kokemusten myötä. Siitä käsin he ennakoivat, mitä tulee tapahtumaan, ja kokevat tietyt kehityskulut mahdollisina ja toiset mahdottomina. Kun natsiupseereille kerrotaan päätöksestä tappaa kaikki juutalaiset, osa upseereista ei yksinkertaisesti pidä kuulemaansa mahdollisena, kunnes heidän odotushorisonttinsa vähitellen muuttuu:

"Mutta eihän se ole mahdollista", Callsen sanoi. Hän kuulosti anovalta. [--] Jouduin mittaamattoman kauhun valtaan, mutta pysyttelin rauhallisena [--]. Callsen jatkoi vastusteluaan: "Mutta Herr Standartenführer, useimmat meistä ovat naimisissa, meillä on lapsia. Meiltä ei voi vaatia sitä.” $(\mathrm{H}, 90 .)^{6}$

Romaani kuvaa sitä vähittäistä prosessia, jonka myötä herkästä nuoresta miehestä, joka joutuu uutisen kuultuaan kauhun valtaan, tulee tappamiseen turtunut teollisen joukkotuhokoneiston ratas, joka ei enää pysty kävelemään metsässä ”ajattelematta joukkohautaa" (H, 612). Kuvaamalla tätä mahdollisuustilan muutosta kertomuksen muodossa romaani laajenee historiantulkinnaksi, joka osallistaa lukijan eri tavoin kuin historiantutkimus, jolla ei ole käytössään kaunokirjallisuuden kerronnallisten keinojen repertuaaria.

Monessa suhteessa romaanin voi nähdä antavan kaunokirjallisen muodon Hannah Arendtin (1964) ja Christopher Browningin (1992) pahan banaaliutta koskeville teorioille, jotka kuuluvat teoksen keskeisiin interteksteihin. Kansallissosialismia ei mahdollistanut radikaali vaan arkipäiväinen pahuus, joka on kiinteä osa modernin länsimaisen yhteiskunnan toimintalogiikkaa: se perustui viime kädessä tavallisten ihmisten taipumukseen totella käskyjä, hoitaa oma, tarkoin rajattu tehtävänsä yhteiskuntakoneistossa ja pidättyä pohtimasta sen viime kädessä palvelemia päämääriä. Tästä lähtökohdasta romaani kutsuu lukijan pohtimaan, miten kerrottu koskee meitä kaikkia. SS-upseerin näkökulmasta kerrotun kertomuksen kautta lukija voi ymmärtää holokaustin toteuttamiseen osallistuneiden toimijoiden kokemusmaailmaa eri tavoin kuin lukiessaan abstraktia esitystä aiheesta: lukija käy läpi, kuvittelee ja kokee nahoissaan sen ajallisen prosessin, jonka myötä tavallisista ihmisistä tulee kylmäverisiä tappokoneita sen, mitä ihmiselle tapahtuu, kun sota vie häneltä "oikeuden olla tappamatta” (H, 19).

Kansallissosialismin kuvataan romaanissa läpäisevän ihmisten elämismaailman tavalla, joka johtaa vaihtoehdottomuuden ilmapiiriin. Esimerkiksi natsien virkamieskieli ohjaa ihmisiä toimimaan ikään kuin käskyt olisivat väistämättömiä: 
[K]irjeenvaihdossa ja myös keskusteluissa käytettiin enimmäkseen passiivimuotoja kuten "on päätetty, että...", "juutalaisille on järjestetty erityiskohtelu", "hankala tehtävä on suoritettu", ja asiat tapahtuivatkin kuin itsestään, kukaan ei tehnyt mitään, kukaan ei toiminut, [-- ] niin päästiin eroon toiminnasta, jäljelle jäi vain faktoja, raakoja tosiasioita, jotka joko olivat jo olemassa tai odottivat väistämätöntä täyttymistään, kuten Einsatz tai Einbruch[.]

$(\mathrm{H}, 550 .)^{7}$

Kertoja reflektoi kriittisesti tätä natsien tapaa reifioida rakentamansa yhteiskunnallinen järjestys, mutta samalla hän itse toimii pitkälti natsijärjestelmän ehdoilla. Hän mukauttaa toimintansa siten, että muut eivät aavista niitä puolia hänestä - kuten homoseksuaalisuutta - joita hän ei koe mahdolliseksi ilmaista kyseisessä poliittisessa ilmapiirissä. Samalla minäkerronta toimii reifikaatiota vastaan tuodessaan esiin sen, miten historia koostuu ihmisten eri tavoin kokemista tilanteista ja heidän konkreettisista teoistaan ja tekemättä jättämisistään, jotka eivät kuitenkaan ole yksinkertaisia "valintoja”, vaan niitä ehdollistaa tietty historiallinen maailma mahdollisuustilana.

Romaani ei vain kuvita teoriaa pahan banaaliudesta, vaan osallistuu itse - kaunokirjallisin keinoin - pahan banaaliuden ajattelemiseen. Olen samaa mieltä kuin Nielsen, Phelan ja Walsh siitä, että fiktiiviset ja ei-fiktiiviset tekstit (kuten historiankirjoitus) vaativat erilaisia lukutapoja. Nähdäkseni molempien kohdalla kysymys totuudesta on kuitenkin mielekäs. Kirjallisuuden tapauksessa totuus ei ole propositionaalista vaan liittyy tapaan, jolla teos kokonaisuudessaan avaa tulkitsemansa historiallisen maailman. Havainnollistan tätä luomalla silmäyksen Hyväntahtoiset-romaanin lukemisen dynamiikkaan.

\section{Lukemisen dynamiikka}

Hyväntahtoisia on luettu pääasiassa historiallisena romaanina. Tämä ei ole yllättävää, käsitteleehän teos toista maailmansotaa ja holokaustia sen suunnitteluun ja toteuttamiseen osallistuvan henkilöhahmon näkökulmasta. Aue pyrkii heti avausvirkkeestä lähtien vakuuttamaan lukijan siitä, että tämä saa kuulla silminnäkijäkertomuksen siitä, ”miten se meni” (H, 7) eli mitä natsi-Saksan hallitsemassa Euroopassa tapahtui vuosien 1941 ja 1945 välillä. Kertoja esiintyy asiantuntijana paitsi tiedustelutehtävissä toimineen entisen SS-upseerin ominaisuudessa myös oppineena, oikeustieteen tohtorina, joka on perehtynyt suureen määrän natsi-Saksaa käsittelevää tutkimuskirjallisuutta.

Romaanin vastaanotossa ovat painottuneet kysymykset siitä, miten historiallisesti tai psykologisesti uskottava teos on. Esimerkiksi historiantutkija Jeremy Popkin pitää romaania suurelta osin "historiallisesti paikkansapitävänä" muttei voi uskoa, että joku voisi selvitä pään lävistävästä luodista. Popkinille häiritsevintä on kuitenkin se, miten Hyväntahtoiset yhdistää historiallisen ja kuvitteellisen: jos romaanin on tarkoitus olla historiallisesti luotettava, sen pitäisi hänestä nojata vielä systemaattisemmin tutki- 
muksiin, jotka osoittavat, että holokaustin toteuttamiseen osallistuneet miehet olivat pääsääntöisesti "varsin tavallisia yksilöitä, joiden epätavanomainen käytös voidaan selittää arkisilla psykologisilla prosesseilla, kuten rationalisaatiolla, ryhmän normeihin mukautumisella ja auktoriteettiuskolla". Jos taas sen on tarkoitus olla "ei-referentiaalinen mielikuvitusharjoitus", sen ei tulisi ajatella luotaavan natsien psykologisia mekanismeja. Popkinin mielestä romaanin historialliselta luotettavuudelta viedään pohjaa, kun Aue osoittautuu seksuaalisesti poikkeavaksi hirviöksi, joka tappaa äitinsä ja makaa siskonsa kanssa. (Popkin 2012, 189, 196-199.)

Hyväntahtoiset-romaanissa äidinmurha liittyy teoksen myyttiseen kehykseen: romaani viittaa jo otsikossaan Aiskhyloksen Oresteiaan, jonka kolmannessa osassa, Eumenidit, äitinsä tappanut Orestes ja häntä vainoavat raivottaret astuvat Athenen perustaman oikeusistuimen eteen selvittääkseen, onko raivotarten viha oikeutettua; lopuksi Athene muuttaa raivottaret eumenideiksi eli "hyväntahtoisiksi", jotta loputon verikoston ja julmuuden kierre lakkaisi. Romaani on jäsennetty yhtäältä Orestesmyytin mukaan ja toisaalta Bachin barokkisarjojen järjestystä noudattavan seitsemän barokkitanssin mukaan, Toccatasta Gigueen (Littell \& Millet 2007, 9). Nämä kehykset alleviivaavat teoksen luonnetta sanataidekompositiona. Ne osoittavat, että lukemista ohjaavana kysymyksenä se, miten realistinen romaani on kuvitteellisena natsiupseerin muistelmana, ei ole riittävä. Tarkastelkaamme romaanin aloitusta tarkemmin:

Ihmiset, veljeni, antakaa kun kerron, miten se meni. Vastaatte, etten ole teidän veljenne ettekä halua kuulla. Tarina on tosiaankin synkkä, mutta vakuutan että se on myös opettavainen, oikea moraalikertomus. [--] Sitä paitsi saatte nähdä, että tämä koskee teitäkin. $(\mathrm{H}, 7 .)^{8}$

Minkälaisen lukijasopimuksen romaani pyrkii rakentamaan? Lukijan puhuttelun kautta se tematisoi heti alussa kysymyksen lukemisen dynamiikasta. Nähdäkseni sopimuksessa, jonka romaani pyrkii solmimaan lukijan kanssa, on olennaista, että se pyytää lukijalta useita asioita samanaikaisesti.

Ensinnäkin romaanin aloitus kutsuu lukijan kuvittelemaan, että tämä lukee SS-upseerin muistelmia tai tunnustuskertomusta. Samalla se kuitenkin myös tekee selväksi, ettei lukijalla ole käsissään tyypillistä historiallista romaania. Lukijasopimuksen toinen keskeinen ulottuvuus rakentuu sen itserefleksiivisestä tasosta, joka vie pohjaa naiivin samaistuvalta lukemiselta ja rakentaa kuvaa omasta konstruktioluonteestaan tietoisesta sanataideteoksesta. Jo aloitusvirke on korostuneen kirjallinen ja tihkuu intertekstuaalisia viittauksia. Se sisältää alluusion muun muassa François Villonin (2005, 159) säkeeseen "Frères humains qui après nous vivez" ja Charles Baudelairen Pahan kukkien säkeeseen "Hypocrite lecteur - mon semblable - mon frère" (ks. Koppenfels 2012, 142). Villon puhuttelee lukijaa pyytääkseen tämän myötätuntoa, Baudelaire vaatiakseen tätä tunnustamaan osallisuutensa. Auen tapauksessa puhuttelu tähtää ennen kaikkea lukijan osallisuuden esiin nostamiseen, mutta sen pohjavireenä on myös ajatus 
yhteisestä ihmisyydestä. Intertekstuaaliset viittaukset toimivat samalla synkän tunnustuksellisuuden vastapainona ja rakentavat muistelmiin itseironista, itserefleksiivistä juonnetta. Romaanin myyttinen kehys ylittää kertojan tietoisuuden, ja sen kautta (implisiittinen) tekijä kiinnittää lukijan huomion teoksen luonteeseen kaunokirjallisena kompositiona.

Kolmanneksi avauskappale tematisoi itse lukuprosessin ja lukijan vastarinnan. Se nostaa esiin lukijan kysymyksen siitä, miksi käyttää niin paljon aikaa sellaisen kertomuksen parissa, jota hallitsee "pahan" hahmon, natsiupseerin, ääni. Kertoja pyrkii osallistamaan lukijan esittämällä, että kerrottu koskee myös tätä, ja vaatimalla lukijaa myöntämään, että tämä olisi saattanut toimia samoin:

Katson modernin historian todistaneen, että tietyissä olosuhteissa kaikki tai lähes kaikki tekevät mitä käsketään; ja suokaa anteeksi, muttei ole kovinkaan todennäköistä että te tekisitte poikkeuksen sen enempää kuin minäkään. [--] Ja jos ette usko, teidän on turha jatkaa lukemista. Jos ette ymmärrä ja vain suututte, siitä ei ole hyötyä sen enempää teille kuin minullekaan. $(\mathrm{H}, 22-23 \text {. })^{9}$

Siten romaanin aloitus paitsi osallistaa lukijaa myös jossakin mielessä esittää itsensä kertomuksena, joka ei halua tulla luetuksi. Tällä retorisella keinolla se samanaikaisesti kutsuu lukijaa vuorovaikutukseen ja tuottaa itserefleksiivistä etäisyyttä.

Hyväntahtoiset-romaanin lukemisen dynamiikkaa määrittävä immersiivisyyden ja kriittisen etäisyyden jännitteinen suhde on olennainen, kun arvioidaan teoksen tapaa esittää tulkinta natsi-Saksan historiallisesta maailmasta. ${ }^{10}$ Nähdäkseni juuri tällä yhdistelmällä teos vastaa haasteeseen, jota tutkijat ovat kuvanneet "imaginatiivisen vastarinnan" käsitteellä. Käsite viittaa lukijoiden haluttomuuteen tai kyvyttömyyteen kuvitella asioita, joita teksti kutsuu kuvittelemaan (Gendler 2013). Vaikka meidän on suhteellisen helppoa kuvitella mahdottomia tai kontrafaktuaalisia asiantiloja fiktiivisessä maailmassa, meidän on huomattavasti vaikeampaa, kuten Marco Caracciolo (2013, 31) tiivistää, asettua kuvittelun keinoin sellaisen henkilöhahmon asemaan, "jonka ajatukset ja käyttäytyminen ovat suoraan ristiriidassa omien eettisten arvojemme ja arvostelmiemme kanssa”.

Hyväntahtoiset vastaa lukijan vastarintaan osoittamalla, että on mahdollista samanaikaisesti kuvitella eettisesti kyseenalainen maailmankuva ja arvomaailma ja säilyttää siihen kriittinen etäisyys. Vaikka lukija joutuu tarkastelemaan maailmaa SS-upseerin näkökulmasta, tämä ei merkitse henkilöhahmon näkökulman ja arvojen omaksumista tai hyväksymistä. Kyky kuvitella toinen näkökulma on eri asia kuin tuon näkökulman hyväksyminen. Kun esimerkiksi Nussbaum (2010, 95-109) tuntuu tarkoittavan näkökulman ottamisella jonkinlaista toiseen samaistumista, hermeneuttisesta näkökulmasta kyky tarkastella maailmaa toisen näkökulmasta ei merkitse sulautumista toiseen eikä omista arvoista luopumista. Sen sijaan se merkitsee toisenlaisen näkökulman tai koke- 
misen tavan pohtimista omasta tulkintahorisontista käsin. Se on perspektiivin ottamista, johon sisältyy kriittinen etäisyys. (Ks. Gadamer 1960, 253, 375-290; Meretoja 2014b.) Nähdäkseni romaanin minäkerronta ei tähtää siihen, että lukija omaksuisi minäkertojan arvot, vaan siihen, että lukija joutuu pohtimaan, miten tavalliset ihmiset saattoivat osallistua holokaustin toteuttamiseen ja miten holokaustin mahdollistivat tietyt modernin länsimaisen yhteiskunnan mekanismit, jotka osin vaikuttavat yhä arjessamme.

Romaanin esittämälle historiantulkinnalle on kuitenkin olennaista myös se, että teoksen myyttinen kehys asettuu jännitteiseen suhteeseen romaanin kansanmurhan modernia, banaalia pahuutta korostavan juonteen kanssa. Orestes-myytin kautta romaanin syyllisyyden ja vastuun problematiikka saa kreikkalaisen pohjavireen. Kuten Aue tietää, antiikin Kreikan syyllisyyskäsityksen mukaan olemme vastuussa teoistamme riippumatta siitä, ymmärrämmekö, mitä olemme tehneet (H, 516). Romaani esittää, että lopulta myös holokausti pakenee inhimillistä käsityskykyä, ja siitä huolimatta olemme vastuussa "kuolleille", joille teos on omistettu.

Orestes-myytin ja Bachin barokkisarjojen käyttö jäsennysperiaatteina korostaa, ettei historia itsessään sisällä kerronnallista jäsennystä; kaunokirjallisuuden on tuotava se siihen. Viime kädessä myytti ei kuitenkaan tarjoa minkäänlaista kokonaisselitystä, ja sen käyttö sisältää myös vahvasti parodisen juonteen. Aue rinnastaa raivotarten roolissa toimivat poliisit Clemensin ja Weserin Laureliin ja Hardyyn (H, 657) ja tappaa heidät ennen kuin he ehtivät muuttua "hyväntahtoisiksi". Vastineiden etsiminen myytin eri hahmoille on lopulta turhaa. Myyttisen kehyksen keskeinen funktio on ylittää kertojan tietoisuus ja siten korostaa eroa minäkertojan näkökulman ja teoksen kokonaisuuden välillä: jälkimmäinen ei ole Auen suunnittelema ja rakentama. ${ }^{11}$ Hän on Oresteshahmo, joka ei itse tiedä tappaneensa äitinsä; hän on sokea omalle toiminnalleen ja silti syyllinen. Juuri sokeus nousee keskeiseksi kuvaksi romaanissa, ja se personifioituu loppukohtauksessa sokean hahmossa, jota talutetaan kadulla tykistön pauhatessa ja puna-armeijan vyöryessä Berliiniin: '’Mihin te olette menossa', kysyin huohottaen. 'Emme tiedä', sokea vastasi. - 'Mistä olette tulossa?' kysyin vielä. - 'Emme tiedä sitäkään.' He istuutuivat raunioiden ja romujen keskellä olevalle laatikolle.” (H, 840.) ${ }^{12}$

\section{"Kysymys ilman vastausta"}

Viime vuosina etenkin monet epäluonnollisen narratologian edustajat ovat korostaneet eroa fiktiivisten ja ei-fiktiivisten kertomusten välillä siitä näkökulmasta, että ne vaativat erilaisia lukutapoja. Esimerkiksi Stefan Iversen ja Henrik Skov Nielsen toteavat, että epäluonnollinen narratologia tutkii "tulkinnallisia seurauksia, joita on epäluonnollisten tekniikoiden, skenaarioiden ja strategioiden käytöstä" (Iversen 2013, 151; ks. Nielsen 2013 , 72). He painottavat lukutapoja, jotka pidättyvät naturalisoimasta eli palauttamasta tekstin "outoja", vaikeaselkoisia ja epäkonventionaalisia ominaisuuksia arkikokemuksesta tuttuihin ilmiöihin. 
Iversen $(2013,152)$ esittää, että suhtaudumme esimerkiksi haastatteluihin kommunikaationa, jossa pyrimme ymmärtämään puhujaa, kun taas fiktioon suhtaudumme Immanuel Kantin termein "intressittömästi”, esteettistä mielihyvää tuottavana itsenäisenä artefaktina. Näkemys nojaa tietynlaiseen Kant-tulkintaan perustuvaan esteettisen formalismin perinteeseen, joka usein ongelmallisesti sivuuttaa sen, miten taideteokset toimivat myös maailman hahmottamisen muotoina. Taideteokset ovat merkityskokonaisuuksia, jotka tuottavat paitsi esteettistä mielihyvää myös intellektuaalisia kokemuksia, jotka liittyvät esimerkiksi ihmisenä olemisen mahdollisuuksia koskeviin uusiin oivalluksiin. Jyrkän fakta/fiktio -erottelun pohjalta voi olla vaikea käsitteellistää, miten kaunokirjallinen teos voi onnistua juuri erityisillä esteettisillä keinoillaan esittämään kiinnostavia tulkintoja historiasta ja maailmassa olemisesta ylipäätän.

Eroa voi havainnollistaa Hyväntahtoiset-romaanin kohtauksella, jossa luoti lävistää Auen pään ja jota monet, myös Iversen, ovat kommentoineet. Kohtaus on hämmentänyt lukijoita, koska siinä näennäisen realistisesti rakennettu teksti alkaa rakoilla niin, että realistinen lukutapa käy yhä riittämättömämmäksi. Kohtauksessa ei suoraan kerrota, että luoti osuu päähenkilön otsaan, vaan lukija voi rekonstruoida tapahtuneen vasta jälkikäteen: "Vilkaisin vielä kerran olkani yli, Ivan juoksi minua kohti, mutta huomioni kiinnittyi johonkin otsassani, siinä oli kivennokare tai mahdollisesti hyönteinen, sillä koskettaessani sitä sormeen jäi veripisara.” (H, 361. $)^{13}$ Aue jatkaa matkaa joelle, ja lukijalle käy selväksi realistisen lukutavan riittämättömyys viimeistään silloin, kun Aue sukeltaa jään alle ja näkee siellä aiemmin toisaalla kuolleen hymyilevän toverinsa ja sen jälkeen kiipeää ilma-alukseen, joka pystyy muuttumaan maailman reunan yli kiipeäväksi jättiläishämähäkiksi. Yrittäessään ulostaa Auen suolesta tulee eläviä mehiläisiä ja skorpioneja.

Iversen kuvaa tätä kerrontaa "epäluonnolliseksi” ja esittää, että teoksen lukeminen epäluonnollisen narratologian lähtökohdista mahdollistaa sen näkemisen "arvoituksena" (riddle), joka koskee ennen kaikkea tajunnankuvauksen mahdollisuuksia ja rajoja sekä sitä, minkälainen kertoja Aue on: "Onko Aue epäluotettava? Epäuskottava? Epätodennäköinen? Epäluotettava? Epäluonnollinen?” Iversenin mukaan kyse on viime kädessä tajunnankuvausta koskevasta esteettisestä kokeilusta. (Iversen 2013, 155-156.)

Olen samaa mieltä siitä, että teoksen ytimessä on arvoitus ja että tuolle arvoitukselle on olennaista sen ratkeamattomuus. En ole kuitenkaan vakuuttunut tulkinnasta, jonka mukaan arvoitus koskisi ensisijaisesti tajunnankuvausta. On kysyttävä, mikä merkitys teoksen "ei-konventionaalisella" kerronnalla on teoksen kokonaisuuden kannalta. Teoksen kerronnalliset erityispiirteet nivoutuvat yhteen teoksen tematiikan kanssa, ja niistä yhdessä rakentuu teoksen kokonaisuus. Nähdäkseni tulkinnallisesti keskeistä on, että haavoittuminen merkitsee kerronnassa murtumaa, josta alkaa kerronnan fragmentoituminen ja kerronnallisen hallinnan hajoaminen. Tämä liittyy Auen kokemusten irtautumiseen intersubjektiivisesta todellisuudesta. Haavoittumisen jälkeen seuraa sarja 
hallusinatorisia tajunnanvirtakuvauksia, joista on vaikea tietää, onko kyse unista, aistiharhoista vai jonkinlaisesta Auen kokemusten rekonstruktiosta. Kertova minä (vanha Aue) ei enää jäsennä kerrontaa retrospektiiviseen muotoon, vaan kertova minä sulautuu kokevaan minään. Tällöin desorientaation kokemus läpäisee yhä voimakkaammin itse kerronnan rakennetta (vrt. Suleiman 2012, 116).

Haavoittuminen murtaa Auen kyvyn kerronnalliseen merkityksenantoon. Hän kokee, ettei pysty enää liittämään asioita yhteen ja ettei sanoista muodostu "minkäänlaista kertomusta” (H, 378). Luodin päähän jättämä reikä saa teoksessa symbolisen merkityksen. Se ilmentää koko romaanin ytimessä olevaa aukkoa, jonka ympärille Auen suhde maailmaan alkaa kiertyä: "Käsitykseni maailmasta järjestyisi nyt tuon reiän ympärille.” (H, 379. $)^{14}$ Mutta reikä ilmentää romaanin keskiössä olevaa aukkoa myös laajemmassa mielessä: kaikki selitykset ja kertomukset eivät voi poistaa sitä, että lopulta kaiken keskellä on sokea piste, aukko, jota emme voi nähdä, ymmärtää tai selittää.

Juuri kerronnallisen hallinnan kyseenalaistamisen kautta teos ottaa kantaa keskusteluun holokaustin esittämisen etiikasta. Teoksen kokonaisuudesta välittyy näkemys, jonka mukaan holokausti ei ole viime kädessä selitettävissä, vaan se jää ihmiskuntaa piinaavaksi, avoimeksi kysymykseksi: "[M]inulle, kuten useimmille, sota ja murha ovat kysymys, kysymys ilman vastausta, sillä kun huutaa yöhön, kukaan ei vastaa." (H, 25.) $)^{15}$ Nähdäkseni Claude Lanzmann (2006) ja muut kriitikot, jotka ovat pitäneet romaania eettisesti kyseenalaisena, eivät ole riittävästi huomioineet tätä romaanin kysymysluonnetta. ${ }^{16}$ Vaikka Hyväntahtoiset asettuu perinteeseen, joka ei (toisin kuin Lanzmann) hyväksy niin sanottua representaatiokieltoa, ajatusta siitä, että holokaustin kuvaaminen taiteellisen representaation muodossa on eettisesti kyseenalaista, on tärkeää, että se ei myöskään esitä tarjoavansa kokonaisvaltaista selitystä tai representaatiota. Samalla kun se kysyy, miten holokausti oli mahdollinen, se pohtii holokaustin ymmärtämisen, esittämisen ja kerronnallistamisen mahdollisuutta ja rajoja. Romaani esittää, että meillä on velvollisuus yrittää ymmärtää, miten holokausti saattoi olla mahdollinen, ja samalla tunnustaa käsityskykymme rajat. Romaanin historiantulkinnassa holokausti on ennen kaikkea kysymys vailla vastausta, mutta samalla - tai juuri siksi - kysymys, jota jokaisen uuden sukupolven on välttämätöntä pohtia omasta näkökulmastaan.

\section{Lopuksi}

Olen artikkelissani hahmotellut sellaista hermeneuttista fiktion teoriaa, jossa kaunokirjallisuuden nähdään toimivan maailman tulkintana tavalla, joka pakenee referentiaalinen-ei-referentiaalinen -dikotomiaa ja problematisoi aktuaalisen ja mahdollisen vastakkainasettelun. Tästä näkökulmasta Hyväntahtoiset-romaanin kerronnalliset kokeilut eivät näyttäydy ainoastaan esteettisenä leikkinä, vaan voidaan analysoida niitä monisyisiä tapoja, joilla teoksen kerronnallinen dynamiikka samanaikaisesti kutsuu 
kuvittelemaan vieraan kokemusmaailman ja tuottaa siihen kriittistä etäisyyttä. Tämä dynamiikka mahdollistaa natsi-Saksassa kulminoituvan arkipäiväisen pahuuden ja välineellisen rationaalisuuden käsittelyn kokemuksellisesti, kokonaisvaltaista emotionaalista osallistumista vaativalla tavalla ilman, että tämä edellyttää lukijalta kritiikitöntä samaistumista natsipäähenkilöön. Esitänkin, ettei näkökulman ottamista tulisi ajatella ainoastaan samaistumisena, vaan sitä voi läpäistä samanaikaisesti emotionaalinen vuorovaikutus ja kriittinen etäisyydenotto.

Artikkelini pohjalta voidaan ajatella, että yksi tärkeä tapa, jolla kaunokirjallisuus voi tuottaa sille erityistä ymmärrystä historiasta, on sen kyky kultivoida omilla kaunokirjallisilla keinoillaan historian tajua nimenomaan mahdollisen tajuna: tajuamme siitä, mitä tietyssä maailmassa oli mahdollista ajatella, kokea, tuntea, tehdä ja kuvitella, mitä taas vaikeaa tai mahdotonta. Valotin analyysissäni, miten Hyväntahtoiset tulkitsee natsi-Saksaa tietynlaisia kokemisen, puhumisen ja toiminnan tapoja tuottavana mahdollisuustilana ja miten se tuo samanaikaisesti esiin sekä tarpeen käsitellä holokaustia kertomuksen muodossa että kerronnallisen haltuunoton mahdottomuuden.

Nähdäkseni sekä fiktiivisten että historiantutkimuksellisten kertomusten käsittäminen tulkintoina mahdollistaa paremmin kuin referentiaalisen ja ei-referentiaalisen tai aktuaalisen ja mahdollisen vastakkainasettelu sen hahmottamisen, miten sekä historiankirjoitus että kaunokirjallisuus voivat pyrkiä kuvittelemaan mennyttä maailmaa mahdollisuustilana. Tämän yhteyden hahmottamisen pohjalta voidaan edetä sen pohtimiseen, mitkä ovat kaunokirjallisuudelle erityisiä historiantulkinnan muotoja ja minkälaisia lukutapoja ne vaativat. Tästä lähtökohdasta on kiinnostavaa analysoida erilaisia tapoja, joilla kaunokirjallisuus voi laajentaa toiminnan, ajattelun ja kokemisen rajojamme kultivoimalla historian tajuamme mahdollisen tajuna - kykyämme kuvitella, mikä koettiin mahdolliseksi menneessä maailmassa ja minkälaisia mahdollisuuksia menneisyyden tulkinta avaa meille nykyajassa.

\section{Viitteet}

${ }^{1}$ Narratiivisesta hermeneutiikasta ks. Brockmeier \& Meretoja 2014; Meretoja 2014c, 18-26.

${ }^{2}$ Corbin 2002, 9; Salmi 2011, 176-177. Sen sijaan narratologiaa hallitsee tapahtumahistoriaa painottava historiakäsitys. Esimerkiksi Fludernikin $(2010,46)$ määrittelyssä "historiallinen" viittaa sellaisiin "historiallisesti merkittäviin" tapahtumiin kuin sotiin, amerikkalaisten kuulentoon ja Berliinin muurin murtumiseen.

${ }^{3}$ Sekä historian että fiktion näkeminen tulkintana ottaa huomioon sen Hayden Whiten jälkeisen tietoisuuden, että historiankirjoitus kerronnallistaa historiaa, mutta tulkinnallisuutta korostava näkemys ei esitä kerronnallistamisen tekevän historiasta fiktiota - kanta, jonka ongelmallisuutta monet fiktion erityisyyttä puolustavat teoreetikot ovat korostaneet.

4 "Je songeai à ces Ukrainiens: comment en étaient-ils arrivés là? La plupart d'entre eux s'étaient battus contre les Polonais, puis contre les Soviétiques, ils devaient avoir rêvé d'un avenir meilleur, pour eux et pour leurs enfants, et voilà que maintenant ils se retrouvaient dans 
une forêt, portant un uniforme étranger et tuant des gens qui ne leur avaient rien fait, sans raison qu'ils puissent comprendre. Que pouvaient-ils penser de cela? [--] Que penseraient-ils de tout cela plus tard?” (Les Bienveillantes, 86; tästä eteenpäin B.)

5 "Je pensais à ma vie, au rapport qu'il pouvait bien y avoir entre cette vie que j'avais vécue [--] et ce qui se passait ici." (B, 95.)

6 "'Mais c'est impossible, voyons', dit Callsen. Il semblait supplier. [--] Je me sentais envahi par une horreur sans bornes, mais je restais calme [--]. Callsen continuait ses objections: 'Mais, Herr Standartenführer, la plupart d'entre nous sont mariés, nous avons des enfants. On ne peut pas nous demander ça."” (B, 99.)

7 "[D]ans les correspondances, dans les discours aussi, les tournures passives dominaient, 'il a été décidé que...', 'les Juifs ont été convoyés aux mesures spéciales', 'cette tâche difficile a été accomplie', et ainsi les choses se faisaient toutes seules, personne ne faisait jamais rien, personne n'agissait, [--] il y avait seulement des faits, des réalités brutes soit déjà présentes, soit attendant leur accomplissement inévitable, comme l'Einsatz, ou l'Einbruch[.]" (B, 581.)

8 "Frères humains, laissez-moi vous raconter comment ça s'est passé. On n'est pas votre frère, rétorquerez-vous, et on ne veut pas le savoir. Et c'est bien vrai qu'il s'agit d'une sombre histoire, mais édifiant aussi, un véritable conte moral, je vous l'assure. [-- Et puis ça vous concerne: vous verrez bien que ça vous concerne.” $(\mathrm{B}, 11$.

9 "Je pense qu'il m'est permis de conclure comme un fait établi par l'histoire moderne que tout le monde, ou presque, dans un ensemble de circonstances donné, fait ce qu'on lui dit; et, excusez-moi, il y a peu de chances pour que vous soyez l'exception, pas plus que moi. [--] Et si vous n'en êtes pas convaincu, inutile de lire plus loin. Vous ne comprendrez rien et vous vous fâcherez, sans profit ni pour vous ni pour moi.” (B, 26-28.)

${ }^{10}$ Kuten Merja Polvinen (2012) tuo esiin, metafiktiivisyys ja immersiivisyys toimivat usein teksteissä samanaikaisesti, eivätkä ole toisensa poissulkevia, toisin kuin monet kognitiivisen narratologian edustajat näyttävät olettavan. Tämä kytkeytyy artikkelikokoelmaa Rethinking Mimesis läpäisevään näkemykseen mimesiksestä ei vain jäljittelynä vaan myös maailmaa rakentavana toimintana - näkemykseen, joka on keskeinen Ricœurille ja laajemminkin artikkelissani hahmottelemalleni hermeneuttiselle perinteelle.

${ }^{11}$ Teoksen kokonaisuuteen voi viitata sisäistekijän käsitteellä (ks. esim. Lothe 2013), mutta kysymyksenasetteluni kannalta "teoksen kokonaisuus" on riittävä luonnehdinta, joten rajaan sisäistekijäkeskustelun artikkelini ulkopuolelle. Aue viittaa "hyväntahtoisiin” vain kerran, viimeisessä virkkeessä, jossa Clemens ja Weser ovat jo kuolleet ja hän on "yksin ajan ja surun ja muistamisen tuskan kanssa": "Hyväntahtoiset olivat taas jäljilläni." (H, 845; "Les Bienveillantes avaient retrouvé ma trace." B, 894.) Hän tuntuu viittaavan "hyväntahtoisilla" lähinnä "menneisyyden painoon", ehkä myös "kuolleisiin", joille romaani on omistettu ja joiden vuoksi meillä on velvollisuus muistaa ja yrittää ymmärtää tapahtunutta, ei koston näkökulmasta - raivotarten sijaan on puhe hyväntahtoisista - vaan siksi, että väkivallan kierre voisi loppua.

12 "'Où allez-vous?' demandai-je en pantelant. - 'Nous ne savons pas', répondit l'aveugle. -'D’où venez-vous?' demandai-je encore. - 'Nous ne le savons pas non plus.'” (B, 889.)

13 "Ivan courait vers moi, mais je fus distrait par un léger heurt sur mon front: un morceau de gravier, peut-être, ou un insecte, car lorsque je me tâtai, une petite goutte de sang perlait sur mon doigt." (B, 383.) 
14 "Ma pensée du monde devait maintenant se réorganiser autour de ce trou." (B, 404.)

15 " $[\mathrm{P}]$ our moi, comme pour la plupart des gens, la guerre et le meurtre sont une question, une question sans réponse, car lorsqu'on crie dans la nuit, personne ne répond.” (B, 30.)

${ }^{16}$ Ylipäätään kertomusta, joka sisältää oman kerronnallisen luonteensa ja kerronnan rajojen reflektiota, ei voi pitää samalla tavoin jo lähtökohtaisesti eettisesti ongelmallisena muotona kuin totalisoivana kokonaisselityksenä esiintyvää kertomusta (ks. Meretoja 2014c, 86-118, 207-214).

\section{Lähteet}

\section{Primäärilähteet}

Littell, Jonathan 2006. Les Bienveillantes [= B]. Paris: Gallimard.

Littell, Jonathan 2008. Hyväntahtoiset $[=\mathrm{H}]$. (Les Bienveillantes, 2006.) Suom. Ville Keynäs. Helsinki: WSOY.

\section{Sekundäärilähteet}

Arendt, Hannah 1964. Eichmann in Jerusalem. A Report on the Banality of Evil. New York: Viking Press.

Beevor, Antony 2009. The Kindly Ones by Jonathan Littell. The Times. 20.2.2009.

Brockmeier, Jens \& Hanna Meretoja 2014. Understanding Narrative Hermeneutics. Storyworlds 6(2), 1-27.

Browning, Christopher 1992. Ordinary Men. Reserve Police Battalion 101 and the Final Solution in Poland. New York: HarperCollins.

Caracciolo, Marco 2013. Patterns of Cognitive Dissonance in Readers' Engagement with Characters. Enthymema VIII, 21-37.

Cohn, Dorrit 2006. Fiktion mieli. (The Distinction of Fiction, 1999.) Suom. Paula Korhonen, Markku Lehtimäki, Kai Mikkonen \& Sanna Palomäki. Helsinki: Gaudeamus.

Corbin, Alain 2002. Le monde retrouvé de Louis-François Pinagot: Sur les traces d'un inconnu (1798-1876). Paris: Flammarion.

Doležel, Lubomír 2010. Possible Worlds of Fiction and History. Baltimore: Johns Hopkins University Press.

Fludernik, Monika 2010. Experience, Experientiality and Historical Narrative: A View from Narratology. T. Breyer \& D. Creutz (eds), Erfahrung und Geschichte. Historische Sinnbildung diesseits des narrativistischen Paradigmas. Berlin: De Gruyter, 40-72.

Foucault, Michel 1966. Les mots et les choses. Paris: Gallimard.

Frege, Gottlob 2008. Über Sinn und Bedeutung (1892). Funktion, Begriff, Bedeutung. Göttingen: Vandenhoeck \& Ruprecht.

Gadamer, Hans-Georg 1960. Wahrheit und Methode. Tübingen: Mohr. 
Gendler, Tamer 2013. Imagination. Edward N. Zalta (ed.), Stanford Encyclopedia of Philosophy. Fall 2013 Edition. http://plato.stanford.edu/archives/fall2013/entries/ imagination/ (14.2.2015).

Heidegger, Martin 1927. Sein und Zeit. Tübingen: Niemeyer.

Iversen, Stefan 2013. Broken or Unnatural? On the Distinction of Fiction in NonConventional First Person Narration. Matti Hyvärinen, Mari Hatavara \& Lars-Christer Hydén (eds), The Travelling Concepts of Narrative. Amsterdam: John Benjamins, 141-162.

Koppenfels, Martin von 2012. “The Infamous “I”: Notes on Littell and Céline.” Aurélie Barjonet \& Liran Razinsky (eds), Writing the Holocaust Today. Critical Perspectives on Jonathan Littell's The Kindly Ones. Amsterdam: Rodopi, 133-152.

Koselleck, Reinhart 1979. Vergangene Zukunft. Frankfurt am Main: Suhrkamp.

Lanzmann, Claude 2006. Lanzmann juge Les Bienveillantes. Le Nouvel Observateur 21.9.2006.

Littell, Jonathan \& Richard Millet 2007. Conversation à Beyrouth. Le Débat 144, $4-24$.

Lothe, Jakob 2013. Authority, Reliability and the Challenge of Reading. The Narrative Ethics of Jonathan Littell's The Kindly Ones. Jakob Lothe \& Jeremy Hawthorn (eds), Narrative Ethics. Amsterdam: Rodopi, 103-118.

Meretoja, Hanna 2014a. Narrative and Human Existence. Ontology, Epistemology, and Ethics. New Literary History 45(1), 89-109.

Meretoja, Hanna 2014b. Nussbaum, hermeneutiikka ja kirjallisuuden eettinen potentiaali. Ajatus 70, 113-148.

Meretoja, Hanna 2014c. The Narrative Turn in Fiction and Theory. The Crisis and Return of Storytelling from Robbe-Grillet to Tournier. Basingstoke \& New York: Palgrave Macmillan.

Nielsen, Henrik Skov 2013. Naturalizing and Unnaturalizing Reading Strategies. Focalization Revisited. Jan Alber, Henrik Skov Nielsen \& Brian Richardson (eds), A Poetics of Unnatural Narrative. Columbus: Ohio State University Press, 67-93.

Nielsen, Henrik Skov, James Phelan \& Richard Walsh 2015. Ten Theses about Fictionality. Narrative 23(1), 61-73.

Nussbaum, Martha 2010. Not for Profit. Why Democracy Needs the Humanities. Princeton: Princeton University Press.

Polvinen, Merja 2012. Being Played. Mimesis, Fictionality and Emotional Engagement. Saija Isomaa, Sari Kivistö, Pirjo Lyytikäinen, Sanna Nyqvist, Merja Polvinen \& Riikka Rossi (eds), Rethinking Mimesis. Concepts and Practices of Literary Representation. Newcastle upon Tyne: Cambridge Scholars Publishing, 93-112. 
Popkin, Jeremy 2012. A Historian's View of The Kindly Ones. Aurélie Barjonet \& Liran Razinsky (eds), Writing the Holocaust Today. Critical Perspectives on Jonathan Littell's The Kindly Ones. Amsterdam: Rodopi, 187-200.

Ricour, Paul 1985. Temps et récit 3. Paris: Seuil.

Salmi, Hannu 2011. Cultural History, the Possible, and the Principle of Plenitude. History and Theory 50, 171-187.

Semprún, Jorge 2008. Ohne die Literatur stirbt die Erinnerung. Frankfurter Allgemeine Zeitung. Feuilleton 33 (8.2.2008), 35.

Suleiman, Susan 2012. Performing the Perpetrator as Witness. Jonathan Littell's Les Bienveillantes. Jakob Lothe, Susan Rubin Suleiman \& James Phelan (eds), After Testimony. The Ethics and Aesthetics of Holocaust Narrative for the Future. Columbus: Ohio State University Press, 99-119.

Villon, François 2005. Euvres complètes: Le Lais, Le Testament, Poésies diverses, Jargon et Jobelin. Ed. Claude Pinganaud. Paris: Arléa. 